\title{
Production and mechanical evaluation of biodegradable composites by white rot fungi
}

\author{
Produção e avaliação mecânica de compósitos biodegradáveis por \\ fungos de podridão branca
}

\author{
Juan Lopes Teixeira' ${ }^{1}$, Maxwell Paca Matos ${ }^{1}$, Brenno Lima Nascimento², Sandro Griza², \\ Francisco Sandro Rodrigues Holanda ${ }^{1}$, Regina Helena Marino ${ }^{1 *}$
}

'Universidade Federal de Sergipe/UFS, Departamento de Engenharia Agronômica, São Cristóvão, SE, Brasil

Universidade Federal de Sergipe/UFS, Departamento de Ciência e Engenharia de Materiais, São Cristóvão, SE, Brasil

${ }^{*}$ Corresponding author: rehmarino@hotmail.com

Received in September 27, 2018 and approved in November 14, 2018

\begin{abstract}
The production of plastic packing grows worldwide, resulting in the accumulation of these materials in the environment due to improper disposal and problems related to degradation. Alternatively, composites produced with agricultural residues and filamentous fungi may exhibit physical and mechanical properties similar to or greater than expanded polystyrene, depending on the fungal species and substrate of the cultivation. In the literature, no reports were found on the use of coconut powder and edible fungi of white rot in the mechanical properties of composites. Thus, the objective of this work was to select fungal isolates and to evaluate the period of cultivation in the mechanical resistance of composites produced in coconut powder supplemented with wheat bran. The experimental design was completely randomized in a $5 \times 3$ factorial scheme corresponding to the cultivation of five edible fungal isolates (Pleurotus ostreatus: POS-W, POS-SP1, POS-98/38; Pleurotus eryngii: POS ER and Pycnoporus sanguineus: PS) and three culture periods after complete colonization of the substrate (15, 30 and 45 days), with four replications. The period of cultivation of the fungal isolates may influence in the composite mass loss and volume loss. The compressive strength and tenacity of the composite are influenced by the fungal isolate and the time of cultivation. The isolates of Pycnoporus sanguineus, Pleurotus ostreatus and P. eryngii present potential characteristics for the production of biodegradable composites.
\end{abstract}

Index terms: Biotechnology; edible fungi; coconut powder.

\section{RESUMO}

A produção de embalagens plásticas cresce mundialmente, o que resulta no acúmulo destes materiais no ambiente devido ao descarte inadequado e por serem de difícil decomposição. De forma alternativa, os compósitos produzidos com resíduos agrícolas e fungos filamentosos podem apresentar propriedades físicas e mecânicas similares ou superiores ao poliestireno expandido, a depender da espécie fúngica e do substrato de cultivo. Na literatura, não foram encontrados relatos sobre o emprego de pó de coco e fungos comestíveis de podridão branca nas propriedades mecânicas de compósitos. Assim, o objetivo deste trabalho foi selecionar isolados fúngicos e avaliar o período de cultivo na resistência mecânica de compósitos produzidos em pó de coco suplementado com farelo de trigo. O delineamento experimental utilizado foi inteiramente ao acaso em esquema fatorial $5 \times 3$ correspondente ao cultivo de cinco isolados fúngicos comestíveis (Pleurotus ostreatus - POS-W, POS-SP1 e POS-98/38; Pleurotus eryngii - POS ER e Pycnoporus sanguineus - PS) e três períodos de cultivo após a completa colonização do substrato (15, 30 e 45 dias), com quatro repetições. O período de cultivo dos isolados fúngicos pode influenciar na perda de massa e de volume do compósito. A resistência à compressão e a tenacidade do compósito são influenciadas pelo isolado fúngico e pelo tempo de cultivo do fungo. Os isolados de Pycnoporus sanguineus, de Pleurotus ostreatus e P. eryngii apresentam características para produção de compósitos biodegradáveis.

Termos para indexação: Biotecnologia; fungos comestíveis; pó de coco.

\section{INTRODUCTION}

Expanded polystyrene (EPS) is a polymer widely used in the manufacture of packaging and structural composites with various industrial application, because it has an attribute of lightness, non-hydrophilic, easy to handle, with low thermal conductivity and high resistance (Strecker; Silva; Panzera, 2014; Borges; Gonçalves Júnior; Almeida, 2017).
In the enviroment, the EPS is slow degraded and persist for over 200 years, as it is impervious to water and does not provide nutrients for the development of decomposing organisms (Franchetti; Marconato, 2006; Souza; Assis, 2014), as well as by the inadequate disposal, which has resulted in accumulation of this material in the environment.

The green polymers appeared with an alternative to the plastic composites produced with substances 
derived from petroleum, in which the vegetal fibers make possible the obtaining of a material with physical and mechanical properties equal or similar to the EPS (Morais; Gadioli; Paoli, 2016; Fernandes et al., 2017; Xie et al., 2018), but with the advantage of being biodegradable (Landim et al., 2016). Thus, the use of coconut powder in the production of composites represents an innovative technological advance, because only a portion of the coconut shell is reused, after the consumption of water, in the manufacture of pots and substrate for production of seedlings. Analogue to green polymers, the composites produced by filamentous fungi have been highlighted as a biodegradable material and alternative to the EPS for use in several economic sectors (Zeller; Zocher, 2012; RománRamos; Luna-Molina; Bailón-Pérez, 2014).

The filamentous fungi promote the aggregation of the particles of the composites residues by the action of the chitin present in the cell wall (Islam et al., 2017; Yang et al., 2017), and also the hypha releases oxidative extracellular enzymes that promote the substrate degradation (Hernández et al., 2017), which contributes to the growth and increase of the mycelial density depending on the time of cultivation and the type of substrate (Haneef et al., 2017). The increase in mycelial density results in physical and mechanical properties of the composites equal to or higher than those produced in EPS (Zeller; Zocher, 2012; Ramirez-Chen et al., 2014), but with the advantage absence of toxic and reducing the release of carbon dioxide in the environment (Arifin; Yusuf, 2013; Tudryn et al., 2018) and not be flammable (Hemmati; Garmabi; 2012).

In the literature, filamentous fungi as: Aspegillus nidulans (Zhao et al., 2018), Agaricus bisporus (RománRamos; Luna-Molina; Bailón-Pérez, 2014), Lentinula edodes and Pleurotus eryngii (Hemmati; Garmabi, 2012), Pleurotus ostreatus (Hidayat; Tachibana; 2012; RománRamos; Luna-Molina; Bailón-Pérez, 2014; Haneef et al., 2017), Phaenerochaete chrysosporium (Ramirez-Chan et al., 2014) were described in the production of biocomposites. Among these species of fungi, those belonging to the Phylum Basidiomycota as Agaricus sp., Lentinula edodes, Pleurotus spp. e Pycnoporus spp. denominated as white rot are distinguished by the presence of oxidative enzymes capable of degrading lignin (Hernández et al., 2017).

The composites colonized by fungi of white rot can be used in the production of packages (Zeller; Zocher, 2012), acoustic coatings (Pelletier et al., 2013), and thermal insulator (Haneef et al., 2017). Different from EPS, fungal composites, after use, can be reused as an animal supplement, organic fertilizer, soil conditioner and substrate for the production of substrates for seedlings
(Azevedo et al., 2009; Fontalvo et al., 2013). These fungi promote the partial degradation of agricultural residues and favor the release of nutrients such as nitrogen, and also carbon and organic matter (Martins et al., 2018). The composite colonized by edible fungi to the soil can induce plant resistance to phytopathogens (Assi et al., 2007) or inhibit the action of pathogenic microorganisms (Ishihara et al., 2018), which can reduce the use of pesticides and an alternative to organic farming.

Among the factors that may influence the mechanical properties of fungal composites it is mentioned fungal species, mycelial density, fungus culture period, moisture present in the composite, and type of the substrate and supplementation (Ramírez-Chan et al., 2014; Haneef et al., 2017; Islam et al., 2017, 2018; Yang et al., 2017; Tudryn et al., 2018). There were no studies related to the effect of the cultivation period of the fungus Pycnoporus sanguineus, as well as the potential of the reuse of the coconut powder in the production of fungal composites. Thus, the objective of this work was to select fungal isolates and evaluate the period of cultivation of these microorganisms in the mechanical resistance of the composite produced by the reuse of residues from the coconut manufacturing supplemented with bran.

\section{MATERIAL AND METHODS}

The experimental design was completely randomized in a $5 \times 3$ factorial method, with five fungal isolates (Pleurotus ostreatus: POS-W, POS-SP1; POS98/38; P. eryngii: POS ER and Pycnoporus sanguineus: PS) and three cultivation periods (15, 30 and 45 days) after complete colonization of the substrates, with four replications.

The composites were produced according to the methodology describe in the patent "Bioprodução de embalagens com uso de micélio de fungos comestíveis" deposited in Instituto Nacional da Propriedade Industrial - INPI (Marino et al., 2017a) by this research group. The fungal isolated were grown in coconut powder-based substrate with particles smaller than $1 \mathrm{~mm}$, supplemented with $40 \%$ wheat bran and moistened at $60-70 \%$ with distilled water. The mixture ( $250 \mathrm{~g}$; wet mass) was packed in $1000 \mathrm{ml}$ cylindrical plastic containers. The assembly was autoclaved at $120^{\circ} \mathrm{C}$ and $1 \mathrm{~atm}$ for one hour and repeated after $24 \mathrm{~h}$.

After cooling, 10 grams of the fungal isolates previously produced in the same substrate (coconut powder and wheat bran) were transferred in an aseptic chamber. The fungal isolates were grown at room temperature until complete colonization. 
The analyzed variables were: composite mass, composite volume, mass loss of the composite, volume loss of the composite, compressive strength and tenacity, after fifteen, thirty and forty-five days of complete colonization of the substrate of growing fungal isolates.

The determination of the mass composite was carried out after 0,24 and 96 hours of oven drying with forced air circulation at $60{ }^{\circ} \mathrm{C}$, using a semi-analytical balance. The volume $(\mathrm{V})$ was calculated by the equation: $\mathrm{V}\left(\mathrm{cm}^{3}\right)=\mathbf{q}$ $\mathrm{x} \mathrm{r}^{2} \mathrm{x} \mathrm{h}$, where $\mathrm{r}=$ radius $(\mathrm{cm})$ and $\mathrm{h}=$ height $(\mathrm{cm})$. The measurements were performed with digital caliper after 24 and 96 hours of drying of the composite. The mass loss (PM) was calculated by the equation: PM (\%) = 100 - (final dry mass $x$ 100) / initial fresh mass. The volume loss (PV) was calculated by the equation: PV $(\%)=100$ - (final volume $x$ 100) / initial volume.

The compressive strength analysis, which assesses the ability to withstand a determined strength until the break, were performed on the universal Instron model 3367 machine with a compression speed of $10 \mathrm{~mm} / \mathrm{min}$ until crack formation. The tenacity, which indicates the ability of the composite to absorb energy until the rupture, was calculated as the area under the stress-strain curves.

The mechanical data were processed by the Bluehill 2 software and submitted to analysis of variance. In cases where there was a significant difference, the Tukey test was applied at 5\% probability. Data on mass loss, volume loss and compressive strength were submitted to regression analysis in the Sisvar 5.6 program and the F test was applied at 1 and 5\% probability.

\section{RESULTS AND DISCUSSION}

In the colonization phase of the substrate, white rot fungi such as Lentinula, Agaricus, Pleurotus and Pycnoporus (Bento; Casaril, 2012) release extracellular oxidative enzymes responsible for the decomposition of lignin, hemicellulose, cellulose and pectin of the vegetal residue, which results in the loss of composite mass (Ramirez-Chan et al., 2014).

Faria, Wisbeck and Dias (2015) observed that the colonization of plastic composites by fungi such as Pleurotus ostreatus caused $0.3-3.3 \%$ of the mass loss after 30 days of cultivation. Ramirez-Chan et al. (2014) also cited 1.2 to $2.4 \%$ composite mass loss colonized by Phanerochaete crysosporium white rot fungus in coconut husk fiber (40\%) and recycled plastic (60\%).

Specifically, in composites based on vegetable residues and filamentous fungi, Sales-Campos and Andrade (2011) obtained that the fungus Lentinus strigosus resulted in 42.2 to $58.6 \%$ composite mass loss. Comparatively, the cultivation of the isolates of Pycnoporus sanguineus and Pleurotus spp. on substrate based on coconut powder supplemented with bran resulted on average $72.4 \%$ mass loss (Figure 1a).

The mass loss of the composite was not influenced by the increase of the isolates cultivation period PS, POS 98/38 and POS ER, but in the POS ER treatment, there
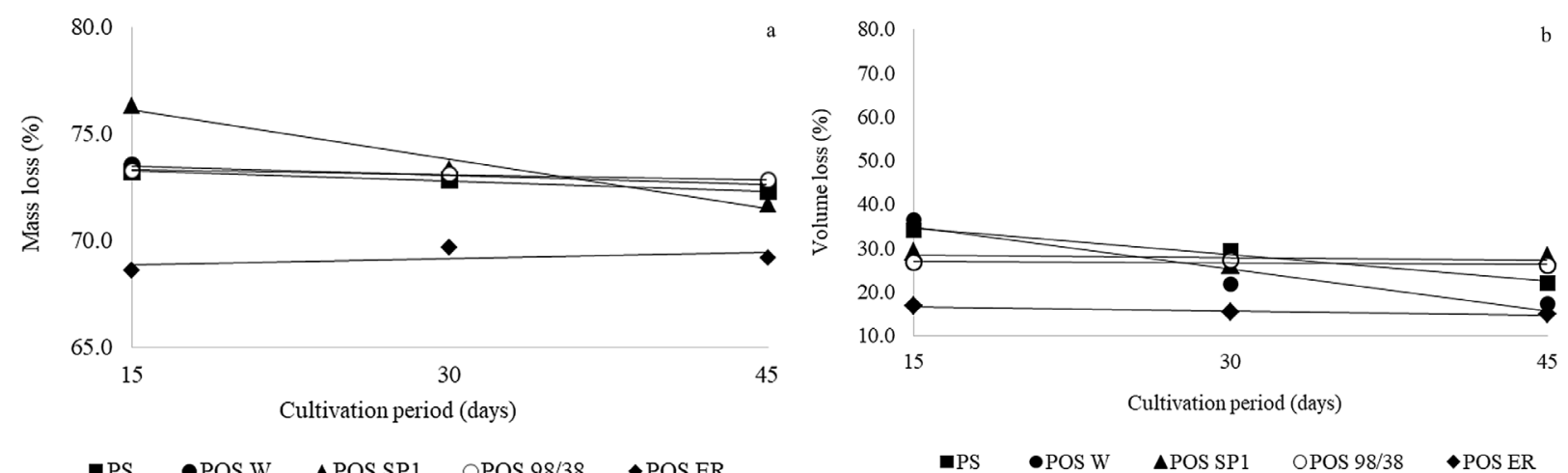

\begin{tabular}{|c|c|c|c|}
\hline -PS & $\triangle \mathrm{POS} \mathrm{SP} 1$ & OPOS $98 / 38$ & $\bullet$ POS ER \\
\hline \multicolumn{4}{|c|}{$P S y=-3.2 E-2 x+73.75 R^{2}=0.99 n s$} \\
\hline \multicolumn{4}{|c|}{$\operatorname{POS} \mathrm{W} y=-0.03 x+73.92 ; \mathrm{R}^{2}=0.99 *$} \\
\hline \multicolumn{4}{|c|}{ POS SP1 y $=-0.15 x+78.45 ; R^{2}=0.97 *$} \\
\hline \multicolumn{4}{|c|}{$\operatorname{POS} 98 / 38 y=-0.02 x+73.53 ; R^{2}=0.96 n s$} \\
\hline POS ER $y=0.0$ & $\mathrm{x}+68.56 ; \mathrm{R}^{2}=0.33 \mathrm{~ns}$ & & \\
\hline
\end{tabular}

Figure 1: Composites mass loss (a) and volume loss (b) colonized by fungal isolates after 15, 30 and 45 days of complete colonization.

ns = not significant $(p>0.05) ;$ * significant at $5 \%(0.01 \leq p<0.05)$ and ** significant at $1 \%(p<0.01)$. 
was the smaller mass loss $(69.2 \%)$. The increase in the cultivation period of the isolates of $P$. ostreatus POS W and POS SP1 significantly reduced the mass loss of composite, whose data were adjusted to the linear regression $(0.01$ $\leq \mathrm{p}<0.05$ ) (Figure 1a), which may result in a lighter bio-packaging similar to isopor ${ }^{\circledR}$ produced in expanded polystyrene.

In the literature, there were not studies on the volume loss in fungal composites, but Hidayat and Tachibana (2012) observed that the fibers of the vegetal residues colonized by Pleurotus ostreatus presented pores by the action of the fungus. Drying the colonized substrate colonized by filamentous fungi may also promote fungal cell channel formation (Scrirp et al., 2006) and / or promote the collapse of hyphae depending on the fungus species (Haneef et al., 2017), which may influence in the composite.

The cultivation of PS isolates of $P$. sanguineus and POS $\mathrm{W}$ of $P$. ostreatus reduced the the volume loss from $35.3 \%$ (15 days) to $19.7 \%$ (45 days) with increasing period, whose data were adjusted to the linear regression $(\mathrm{p}<0.01)$. In the cultivation of POS SP1, POS 98/38 and POS ER of Pleurotus spp., the average volume loss of the composite was $27.8 \%, 26.7 \%$ and $15.7 \%$, respectively, without any influence of the growing period (Figure 1b).

The reduction of the composite volume loss colonized by the PS and POS W isolates with the increase of the culture period, may be correlated with the increase of the mycelial density. Since the higher mycelial density may be due to the branching of the hyphae, which promotes the compaction and reduction of the micropores of the composites (Haneef et al., 2017). During the cultivation of the fungal isolates, the increase in mycelial density was observed, which may have contributed to a higher compaction of the composite microspores, as mentioned by Haneef et al. (2017).

Among the factors that influence mycelial density can be mentioned: the availability of nutrients, such as carbon sources and / or supplementation (Kirsch; Macedo; Teixeira, 2016; Tudryn et al., 2018); type of substrate (Andrade et al., 2013) and culture temperature (Andrade et al., 2010). Considering that the whole bioassay was performed with the same type of substrate, supplementation and cultivated under the same environment and temperature conditions, the difference in mycelial density observed between the treatments was due to the fungal species, as reported by Haneef et al. (2017). According to these authors, Pleurotus ostreatus showed growth of the hyphae in length, whereas Ganoderma lucidum presented hyphae branching, increasing the density of the mycelium, a behavior that may have occurred with Pleurotus eryngii
(POS ER) and Pycnoporus sanguineus (PS) compared to isolates the P. ostreatus tested (POS W, POS SP1 and POS 98/38). It is important to note that the increase in the cultivation period of the Pleurotus spp. e Pycnoporus sanguineus isolates resulted in an increase in mycelial density in all treatments, although the drying did not influence the mycelial density after complete colonization of the substrate (Figure 2).

Román-Ramos, Luna-Molina and Bailón-Pérez (2014) and Yang et al. (2017) mentioned that chitin present in the cell wall aggregates the particles of composite, which can impart similar mechanical resistance to EPS and reduce the occurrence of cracks in the material when subjected to compressive test, as observed in the composites colonized by tested isolates (Figure 2).

According to Islam et al. (2017), the fungi used by the company Ecovative resulted in the production of a biocomposite, which behaves like an open and elastic foam, with values of compressive resistance between 0.06 and $2.00 \mathrm{MPa}$, depending on the density of the composite. Comparatively, Yang et al. (2017) obtained the maximum compressive resistance of 0.069 to $0.400 \mathrm{MPa}$

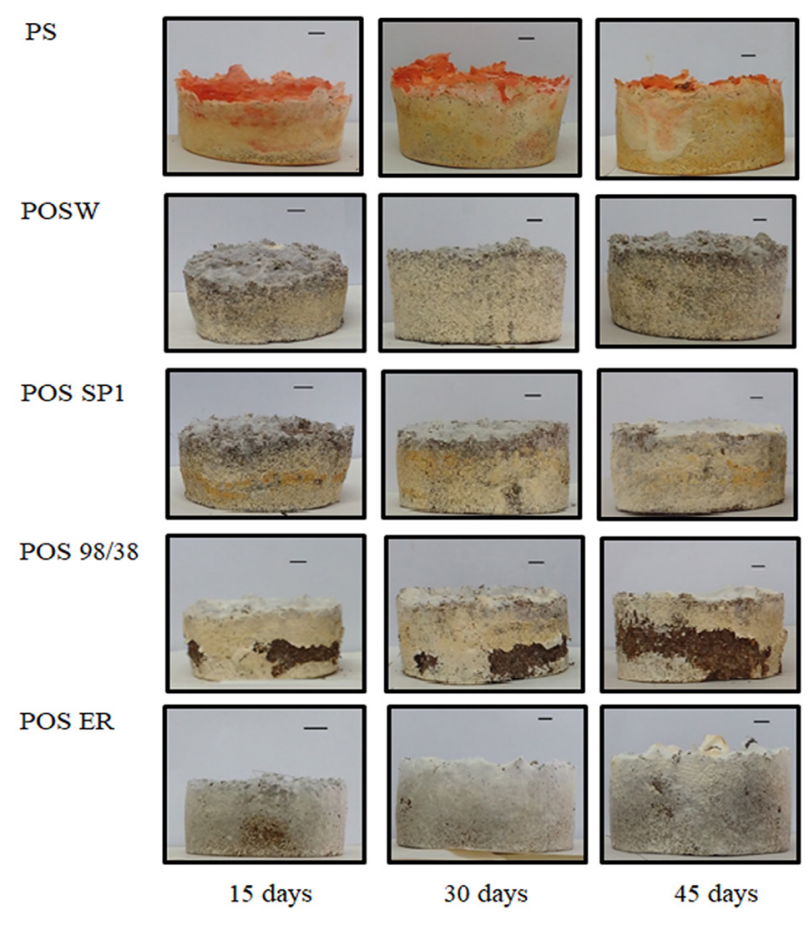

Figure 2: Composites produced in coconut powder supplemented with bran and colonized by $P$. sanguineus (PS), P. ostreatus (POS W, POS SP1 and POS 98/38) and P. eryngii isolates for 15,30 and 45 days after complete colonization of the substrate and subjected to drying. 
in a commercial composite called Biofoam formed by plant residues colonized by filamentous fungi, but without mention of the fungal species. These authors also observed that the increase of the fungus cultivation period contributed to the $60 \%$ increase in the mechanical resistance of the composite, due to the hyphae aggregation action.

In the composite colonized by Pycnoporus sanguineus (PS), the compressive strength of $0.18 \pm 0.05$ MPa was higher than $0.03 \pm 0.02 \mathrm{MPa}$ obtained with other Pleurotus spp. isolates, which shows an increase of 500\% at the mechanical resistance in relation to the other tested fungi (Figure 3).

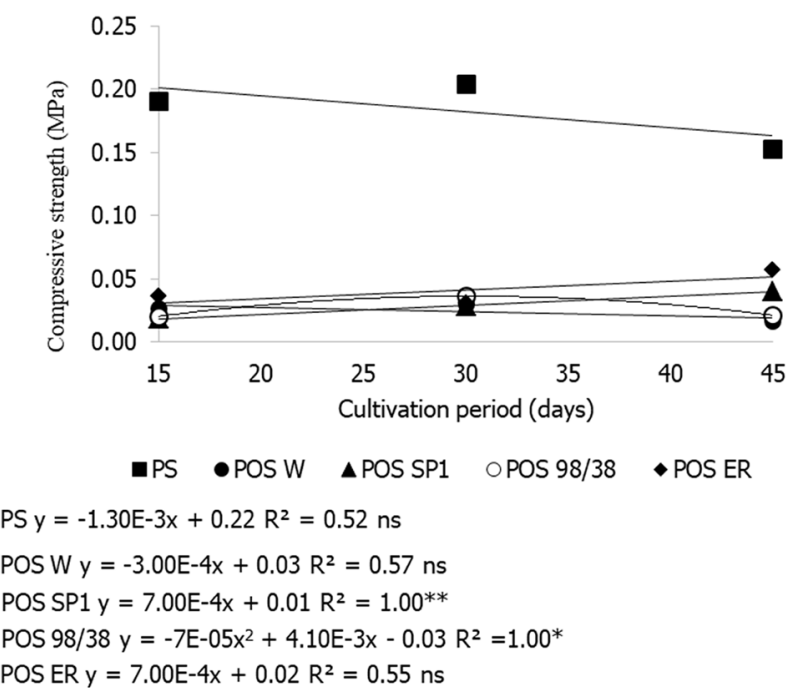

Figure 3: Compressive strength of composites cultivated with $P$. sanguineus (PS), P. ostreatus (POS W, POS SP1, POS 98/38) and P. eryngii (POS ER) after 15, 30 and 45 days complete colonization of the substrate.

ns $=$ not significant $(p>0.05)$; * significant at $5 \%(0.01 \leq p<$ $0.05)$ and ${ }^{* *}$ significant at $1 \%(p<0.01)$.

Carvalho and Fronllini (1999) stated that the compressive strength greater than $0.08 \mathrm{MPa}$, as obtained in PS, characterizes a rigid foam. Román-Ramos, LunaMolina and Bailón-Pérez (2014) observed that the increase in the culture period of Pleurotus ostreatus reduced the compressive strength of the composite. In turn, Haneef et al. (2017) observed that the fungal mechanical resistance of the composite was influenced by the increase of the culture period, depending on the fungal species.

In the composite based on coconut powder and bran, the increase of the culture period did not influence the mechanical resistance of the composites colonized by PS and Pleurotus spp. isolates, except for POS SP1 which showed a 100\% increase in compressive strength of $0.02 \pm 0.01 \mathrm{MPa}$ to $0.04 \pm 0.02 \mathrm{MPa}$ with increase of the cultivation period from 15 to 45 days, whose data were adjusted to linear regression $(\mathrm{p}<0.01)$; and for isolate POS 98/38, the compressive strength of $0.03 \pm 0.01$ MPa to $0.04 \pm 0.01 \mathrm{MPa}$ with increasing colonization period from 15 to 30 days of culture, corresponds to a $50 \%$ increase in mechanical resistance. On the other hand, the compressive strength of the composite of POS 98/38 showed a reduction of $44.4 \%$ with an increase in the cultivation period from 30 to 45 days, whose mean values of $0.04 \pm 0.01 \mathrm{MPa}$ (30 days) for $0.02 \pm 0.01 \mathrm{MPa}$ (45 days) were adjusted to the quadratic regression $(0.01 \leq \mathrm{p}<0.05)$ (Figure 3 ).

Comparatively, the composites colonized by the Pleurotus isolates had a compressive strength lower than that reported for rigid polyurethane foam $(0.05 \mathrm{MPa})$ by Galvão, Farias and Mendes (2015), except POS ER that presented 0.06 $\pm 0.01 \mathrm{MPa}$ at 45 days of culture after complete colonization (Figure 3). However, on average, the composites colonized by Pleurotus spp. can be classified as a semi-rigid foam, because they have a maximum compressive strength between 0.015 and $0.08 \mathrm{MPa}$, according to the classification described in Carvalho and Fronllini's (1999), that said the materials to be packed by this type of material could better absorb the impact and possible breakages.

According to Horvath et al. (1997), the maximum compressive stress of the composites should be considered at $10 \%$ maximum deformation, whose values of mechanical resistance of the EPS depends on the purpose of the material. Similarly, Borges, Gonçalves and Almeida (2017) cited that the EPS can have maximum compressive strength between 0.033 and $0.165 \mathrm{MPa}$, depending on the type of isopor ${ }^{\circledR}$. And Román-Ramos, Luna-Molina and Bailón-Pérez (2014) used as standard for EPS the maximum compressive strength at $10 \%$ deformation of $0.05 \mathrm{MPa}$ for materials intended for the production of packages and values below $0.05 \mathrm{MPa}$ for acoustic insulation.

Considering the maximum compressive strength versus deformation interaction of the composite with $P$. sanguineus (PS), it was observed that there was no influence of the culture period on the mechanical resistance, but the maximum compressive strength at $10 \%$ deformation was on average less than $0.05 \mathrm{MPa}$ (Figure 4), which results in ideal material for acoustic insulation according to the classification of Román-Ramos, Luna-Molina and Bailón-Pérez (2014).

The maximum compressive strength versus deformation of the composite colonized by the PS isolate showed elastic behavior, as observed by Islam et al. (2018). However, there was no change in the elastic behavior with the increase of the culture period, which differs from what was observed by Yang et al. (2017) in the Biofoam composite. 
PS

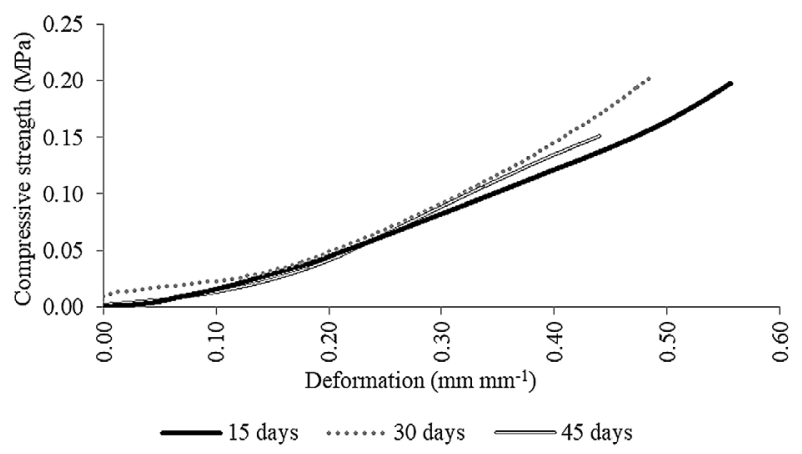

POS W

POS SP1
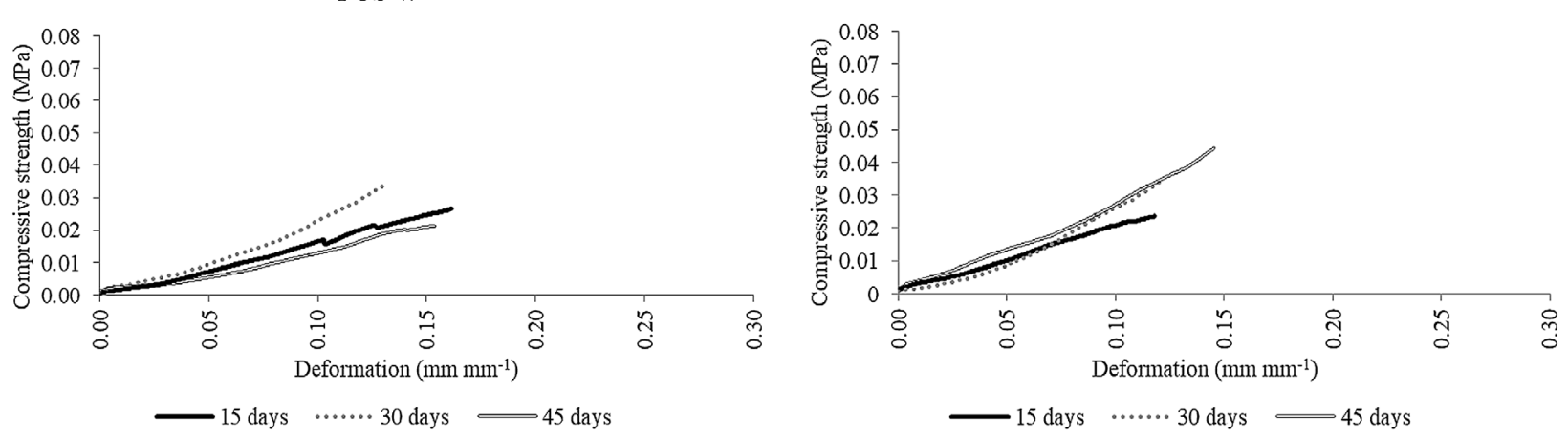

POS 98/38

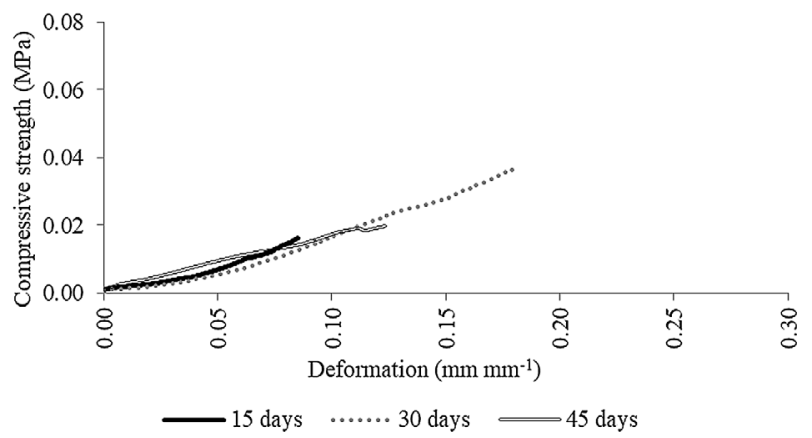

POS ER

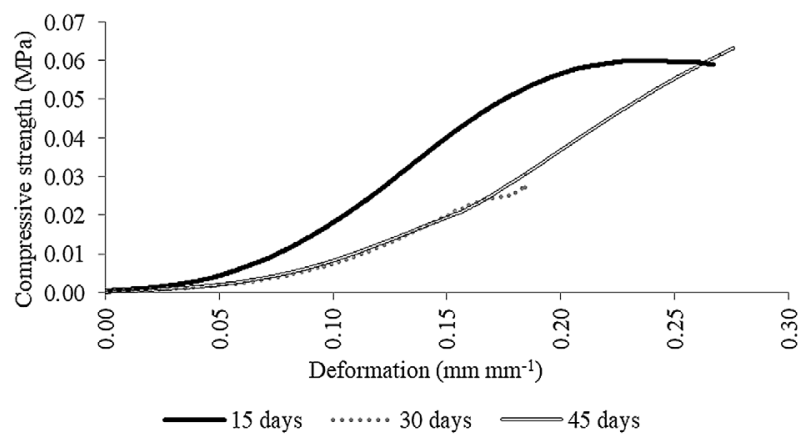

Figure 4: Compressive strength versus deformation of the composite with white rot fungi at 15,30 and 45 days after complete colonization. Means followed by same letters do not differ by Tukey test at $5 \%$ probability.

According to Román-Ramos, Luna-Molina and Bailón-Pérez (2014), the elastic behavior of a composite occurs due to the higher density of the composite, which may be correlated with the lower mycelial density, since the mycelium can promote filling of the micropores of the composite as discussed by Haneef et al. (2017). And the increase in the mycelial density of PS during the cultivation may have favored the elastic behavior of the composite (Figure 4).
The area below the compression curves allows assumptions about the energy absorbed until the appearance of cracks in the composites; and the absorbed energy, in turn, reflects the tenacity of the material. In relation to the degree of energy absorption up to the crack, observed that the composite colonized by PS presented higher tenacity with 15 days of complete mycelial colonization of the substrate and that the increase of the culture period reduced the tenacity of the composite in 32 
to $50 \%$, which characterizes that the material becomes more fragile (Table 1).

Table 1: Mean tenacity $\left(\mathrm{mm}^{2} \times \mathrm{MPa}\right)$ of the test composites from the area of the compressive strength versus deformation curve by time the cultive after complete colonization.

\begin{tabular}{cccc}
\hline \multirow{2}{*}{ Isolates } & \multicolumn{3}{c}{ Tenacity (area $\times$ strength; $\mathrm{mm}^{2} \times \mathrm{MPa}$ ) } \\
\cline { 2 - 4 } & 15 days & 30 days & 45 days \\
\hline PS & 0.0575 & 0.0387 & 0.0285 \\
POS W & 0.0014 & 0.0007 & 0.0012 \\
POS SP1 & 0.0005 & 0.0006 & 0.0010 \\
POS 98/38 & 0.0002 & 0.0019 & 0.0006 \\
POS ER & 0.0064 & 0.0021 & 0.0069 \\
\hline
\end{tabular}

The composites colonized by POS W, POS SP1 and POS 98/38 isolates of Pleurotus ostreatus also presented elastic behavior as observed for PS with increasing culture period (Figure 4). However, for the POS W isolate, it was observed that the composite showed higher tenacity at 15 days compared to 30 and 45 days, which gives higher absorbed energy. In the treatments with POS 98/38 and POS SP1, the composite tenacity was higher at 30 and 45 days of complete colonization of the substrate, resulting in increased mechanical resistance, energy and durability of the material.

The colonized composites by fungi may also exhibit plastic behavior depending on the fungal species (RománRamos; Luna-Molina; Bailón-Pérez, 2014). Specifically, by Pleurotus eryngii isolate (POS ER) it was observed that after 15 days of complete colonization of the substrate, the composite presented a plastic behavior (Figure 1), with a tenacity of $204.7 \%$ higher than the values obtained after 30 days of culture of the fungal isolate (Table 1). This composite (POS ER) presented elastic behavior at 30 days of culture after complete colonization, as well as reduced the tenacity. There was no influence of the increase of the culture period from 30 to 45 days in the elastic behavior of the composite with the POS ER, but there was an increase of $228 \%$ in the tenacity.

The plastic behavior of the materials presents greater capacity to absorb energy and greater durability than elastic composites (Horvath et al., 1997). Thus, for composite production that require higher strength and higher tenacity, the cultive POS ER should be performed preferentially for up to 15 days after complete colonization.

Another important aspect of fungal composites is that they are hydrophobic (Haneef et al., 2017), probably due to the presence of proteins associated with the fungal cell wall (Alexandre; Blanchet; Charpentier, 2000), which allows the use of the composite in several economic sectors, unlike the vegetable composites that are hydrophilic (Fernandes et al., 2017; Xie et al., 2018). In addition, fungal composites are also fire resistant (Hemmati; Garmabi, 2012), because the mycelium acts as a flame-inhibiting agent (Román-Ramos; Luna-Molina; Bailón-Pérez, 2014).

In general, it is possible to use white rot fungi in the production of composites using coconut powderbased substrate supplemented with bran, which represents a biotechnological alternative to reduce environmental contamination caused by the inadequate deposit of isopor ${ }^{\circledR}$, as well as reuse of coconut shells after the consumption of coconut water. In addition, it should be considered that the bio-packaging of fungal origin is biodegradable, and can be reused as a substrate for seedling production, organic fertilizer, soil conditioner (Fontalvo et al., 2013; Martins et al.; 2018; Marino et al., 2017b), unlike isopor ${ }^{\circledR}$ that can persist in the environment for more than 200 years (Franchetti; Marconato, 2006). The use of fungal composites in the soil can induce plant resistance to phytopathogens (Assi et al., 2017) or inhibit the action of pathogenic microorganisms (Ishihara et al., 2018), which may reduce the use of pesticides and an alternative to organic farming.

\section{CONCLUSIONS}

The period of cultivation of the fungal isolates may influence in the composite mass loss and volume loss. The mechanical strength and the tenacity of the composite are influenced by the fungal isolate and the fungus culture period. The isolates of Pycnoporus sanguineus, Pleurotus ostreatus and P. eryngii present potential for the production of biodegradable composites instead of EPS.

\section{REFERENCES}

ALEXANDRE, H.; BLANCHET, S.; CHARPENTIER, C. Identification of a 49-kDa hydrophobic cell wall mannoprotein present in velum yeast which may be implicated in velum formation. Fems Microbiology Letters, 185(1):147-150, 2000.

ANDRADE, M. C. N. et al. Crescimento micelial in vitro de cinco linhagens de Agaricus bisporus submetidas a diferentes condições de temperatura. Acta Scientiarum Agronomy, 32(1):69-72, 2010.

ANDRADE, M. C. et al. Uso de resíduos madeireiros da Amazônia brasileira no cultivo in vitro de Lentinus strigosus. Ambiência, 9(1):189-196, 2013. 
ARIFIN, Y. H.; YUSUF, Y. Mycelium fibers as new resource for environmental sustainability. Procedia Engineering, 53(1):504-508, 2013.

ASSI, L. et al. Desenvolvimento de substratos alternativos para o cultivo de cogumelos comestíveis e medicinal. Scientia Agraria Paranaensis, 6(1):41-51, 2007.

AZEVEDO, R. S. et al. Utilização do composto exaurido de Pleurotus sajor-caju em rações de frangos de corte e seus efeitos no desempenho dessas aves. Acta Scientiarum. Animal Science, 31(2):139-144, 2009.

BENTO, C. B. P.; CASARIL, K. B. P. B. Bioconversão de resíduos agroindustriais ligninocelulósicos por fungos causadores da produção branca: Uma alternativa à produção de alimentos. Revista Unioeste, 14(9):151-180, 2012.

BORGES, E.; GONÇALVES JUNIOR, E. L.; ALMEIDA, I. M. F. Isopedra, suas características físicas ante ao EPSPoliestireno expandido. Revista Científica de Ciências Aplicadas, 4(7):66-77, 2017.

CARVALHO, G. de; FROLLINI, E. Lignina em espumas fenólicas. Polímeros: Ciência e Tecnologia, 9(1):66-75, 1999.

FARIA, P. C.; WISBECK, E.; DIAS, L. P. Biodegradação de prolipropileno recilado (ppr) e de poli (tereftalato de etileno) reciclado (petr) por Pleurotus ostreatus. Revista Matéria, 20(2):452-459, 2015.

FERNANDES, J. R. et al. Nanopartículas de sílica silanizada como compatibilizante em compósitos de fibras de sisal/ polietileno. Polímeros, 27 (n. especial): 61-69, 2017.

FONTALVO, J. A. L. et al. Efecto de residuos agroforestales parcialmente biodegradados por Pleurotus ostreatus (Pleurotaceae) sobre el desarrollo de plántulas de tomate. Acta Biologica Colombiana, 18(2):365-374, 2013.

FRANCHETTI, S. M. M.; MARCONATO,J. C. Polímeros biodegradáveis - Uma solução parcial para diminuir a quantidade dos resíduos plásticos. Química Nova, 29(4):811-816, 2006.

GALVÃO, Á. C. P.; FARIAS, A. C. M.; MENDES, J. U. I. L. Obtenção e caracterização de espumas rígidas de poliuretano (pur) com pó de vidro sodo-cálcico (pv) do rejeito da lapidação. Holos, 5(1):104-118, 2015.

HANEEF, M. et al. Advanced materials from fungal mycelium: Fabrication and tuning of physical properties. Scientific Reports, 7:41292, 2017.

HEMMATI, F.; GARMABI, H. A study on fire retardancy and durability performance of bagasse fiber/polypropylene composite for outdoor applications. Journal of Thermoplastic Composite Material, 26(8):1041-1056, 2012.
HERNÁNDEZ, C. et al. Laccase induction by synthetic dyes in Pycnoporus sanguineus and their possible use for sugar cane bagasse delignification. Applied Microbiology Biotechnology, 101(3):1189-1201, 2017.

HIDAYAT, A.; TACHIBANA, S. Characterization of polylactic acid (PLA)/kenaf composite degradation by immobilized mycelia of Pleurotus ostreatus. International Biodeterioration \& Biodegradation, 71(1):50-54, 2012.

HORVATH, J. S. The compressible inclusion function of EPS geofoam. Geotextiles and Geomembranes, 15(1):77120, 1997.

ISHIHARA, A. et al. Identification of antifungal compounds in the spent mushroom substrate of Lentinula edodes. Journal of Pesticide Science, 43(2):108-113, 2018.

ISLAM, M. R. et al. Morphology and mechanics of fungal mycelium. Scientific reports, 7(13070):1-12, 2017.

ISLAM, M. R. et al. Mechanical behavior of mycelium-based particulate composites. Journal of Materials Science, 53(24):16371-16382, 2018.

KIRSCH, L. S.; MACEDO, A. J. P.; TEIXEIRA, M. F. S. Production of mycelial biomass by the Amazonian edible mushroom Pleurotus albidus. Brazilian Journal of Microbiology, 47(3):658-664, 2016.

LANDIM, A. P. M. et al. Sustentabilidade quanto às embalagens de alimentos no Brasil. Polímeros, 26(1):82-92, 2016.

MARINO, R. H. et al. Bioprodução de embalagens com uso de micélio de fungos comestíveis. Brasil: INPI. Patente de número: BR10201700849, 2017a. Available in: <http:// www.inpi.gov.br/>. Access in: November, 28, 2018.

MARINO, R. H. et al. Composto orgânico de resíduos da fungicultura. Brasil: INPI, 2017b. Patente de número: BR10201700846. Available in: <http://www.inpi.gov.br/>. Access in: November, 28, 2018.

MARTINS, O. G. et al. Sobra de alimentos como alternativa para a formulação de novos substratos para o cultivo de Pleurotus ostreatus (Basidiomycota, Fungi). Revista em Agronegócio e Meio Ambiente, 11(2):505-518, 2018.

MORAIS, J. A.; GADIOLI, R.; PAOLI, M. A. Curaua fiber reinforced high-density polyethylene composites: Effect of impact modifier and fiber loading. Polímeros, 26(2): Epub7, 2016.

PELLETIER, M. G. et al. An evaluation study of mycelium based acoustic absorbers grown on agricultural by-product substrates. Industrial Crops and Products, 51:480-485, 2013. 
RAMIREZ-CHAN, D. E. et al. Effect of accelerated weathering and Phanerochaete chrysosporium on the mechanical properties of a plastic composite prepared with discarded coir and recycled HDPE. Bioresoruces, 9(3):4022-4037, 2014.

ROMÁN-RAMOS, J. D.; LUNA-MOLINA, F. J.; BAILÓN-PÉREZ, L. J. Encofrado perdido constituido por paja cohesionada con micelio como sustituto del poliestireno expandido. Informes de La Construcción, 66(1):01-07, 2014.

SALES-CAMPOS, C.; ANDRADE, M. C. N. Aproveitamento de resíduos madeireiros para o cultivo do cogumelo comestível Lentinus strigosus de ocorrência na Amazônia. Acta Amazonica, 41(1):1-8, 2011.

SCHIRP, A. et al. Production and characterization of natural fiber-reinforced thermoplastic composites using wheat straw modified with the fungus Pleurotus ostreatus. Journal of Applied Polymer Science, 102(6):5192-5201, 2006.

STRECKER, K.; SILVA, C. A.; PANZERA, T. H. Fabricação e caracterização de compósitos a base de cimento com incorporação de poliestireno expandido (isopor). Cerâmica, 60(354):310-315, 2014.
SOUZA, L. M.; ASSIS, C. D. Placas para alvenaria de vedação com uso de espuma de poliestireno expandido (EPS). Revista do Centro do Ciências Naturais e Exatas, 18(2):865-873, 2014.

TUDRYN, G. J. et al. Processing and morphology impacts on mechanical properties of fungal based biopolymer composites. Journal of Polymers and the Environment, 26(4):1473-1483, 2018.

$\mathrm{XIE}, \mathrm{Q}$. et al. A new biodegradable sisal fiber-starch packing composite with nest structure. Carbohydrate Polymers, 189(1):56-64, 2018.

YANG, Z. et al. Physical and mechanical properties of fungal mycelium-based Biofoam. Journal of Materials in Civil Engineering, 29(7):1-9, 2017.

ZELLER, P.; ZOCHER, D. Ecovative's breakthrough biomaterials. Fungi Magazine, 5(1):51-56, 2012.

ZHAO, L. et al. Elastic properties of the cell wall of Aspergillus nidulans studied with atomic force microscopy. Biotechnology Progress, 21(1):292-299, 2018. 